\title{
Faktor-Faktor yang Mempengaruhi Perilaku Kewirausahaan Enterpreneur Muslim Salatiga
}

Mochlasin

Fakultas Ekonomi dan Bisnis Islam IAIN Salatiga

Email: mochlas_sofyan@yahoo.co.id.

Wahyu Krisnawati

Fakultas Ekonomi dan Bisnis Islam IAIN Salatiga

Email: wahyu_krisna@yahoo.com

الملخص

يقتصد هذا البحث معرفة للعوامل التى تؤثر إلى سلوك ريادة الأعمال نهو طاب قسمالخدماتالمصرفيةالإسلامية في كلية اقتتصادوالأعما لـ لإسلامية بجامعة سلاتيجا الإسلامية الحكومية. المتغيرات المستقلة في البحث هي المادة عنريادةالأعمال ثم البيئةوالشخصية.و أما المتغيرالتابع هو السلوك في ريادة الأعمال.

كان عددسكان البحث هو جميع طلاب قسمالخدماتالمصرفيةالإسلامية في كلية [لمتصا دوالأعما

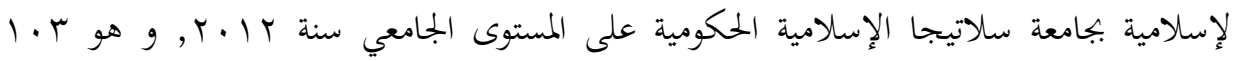
طالبا. ثخم اتخذ العينات من العدد السابق باستعمال أخذ العينات. أما التقنياتالمستخدمة هي التحليل في اختبارالموثّ وقية و الصحية و الإفتراضاتالكلاسيكية ولختباراتالإحصائية. واستخدم اختبارالفرضية إختبار f(uji t), إختبار

كانت نتائجهذهالدراسة تدل على أن المادة و البيئة و الشخصية تؤثر معا في تكوين سلوك ريادة الأعمال. و لكن من ناحية فردية تؤثر المادة السلوك تأثيرا إيجابيا و هاما, و و أما البيئة تؤثرها إيجابيله هاما, و أما الشخصية تؤثرها إيجابيا و هاما. الكلماتالرئيسية: المادة عن ريادة الأعمال والبيئة والشخصية و سلوك ريادة الأعمال 


\begin{abstract}
Abstrak
Penelitian ini bertujuan untuk mengetahui faktor-faktor yang mempengaruhi perilaku kewirausahaan mahasiswa Jurusan Perbankan Syariah Fakultas Ekonomi dan Bisnis Islam IAIN Salatiga. Penelitian ini menggunakan variabel independen pendidikan kewirausahaan, lingkungan dan kepribadian, sedangkan variabel dependennya perilaku kewirausahaan. Populasi dalam penelitian ini adalah mahasiswa Jurusan Perbankan Syariah S-1 Fakultas Ekonomi dan Bisnis Islam IAIN Salatiga angkatan 2012. Jumlah mahasiswanya adalah 103. Pengambilan sampel dengan menggunakan random sampling. Teknik yang digunakan adalah analisis uji reliabilitas, uji validitas, uji asumsi klasik dan uji statistik. Pengujian hipotesis menggunakan uji t, uji $F$ dan $\mathrm{R}^{2}$. Hasil penelitian ini menunjukkan bahwa Pendidikan Kewirausahaan, Lingkungan dan Kepribadian secara bersama-sama (simultan) mempengaruhi Perilaku Kewirausahaan. Akan tetapi jika secara individu Pendidikan Kewirausahaan berpengaruh positif dan signifikan terhadap Perilaku Kewirausahaan, Lingkungan berpengaruh positif tetapi tidak signifikan terhadap Perilaku Kewirausahaan, Kepribadian berpengaruh positif dan signifikan terhadap Perilaku Kewirausahaan.
\end{abstract}

Kata kunci: Pendidikan Kewirausahaan, Lingkungan, Kepribadian dan Perilaku Kewirausahaan.

\title{
Pendahuluan
}

Menurut Indarti dan Rostiani dalam Paulina (2008: 3-4) secara realitas ada tiga pilihan yang kemungkinan akan dialami lulusan Perguruan Tinggi setelah menyelesaikan studinya. Pertama, menjadi pegawai atau karyawan perusahaan swasta, Badan Usaha Milik Negara atau Pegawai Negeri Sipil (PNS). Kedua, kemungkinan menjadi pengangguran intelektual. Ketiga, membuka usaha sendiri (berwirausaha).

Umumnya mereka lebih dipersiapkan menjadi pencari kerja ketimbang pencipta lapangan kerja. Menurut data Dirjen Pemuda dan Pendidikan Luar Sekolah Departemen Pendidikan Nasional dari 75,3 juta pemuda Indonesia, 6,6 persen yang lulus sarjana. Dari jumlah tersebut $82 \%$ nya bekerja pada instansi pemerintah maupun swasta, sementara hanya $18 \%$ yang berusaha sendiri atau menjadi wirausahawan. Hal tersebut menunjukkan 
masih rendahnya para lulusan perguruan tinggi tak berani mengambil pekerjaan beresiko seperti berwirausaha.

Perguruan tinggi juga merupakan sebuah lembaga pendidikan yang turut bertanggung jawab untuk mencetak lulusan yang dapat langsung bekerja. Sehingga tantangan yang ada bagi universitas yang ada di Indonesia adalah bagaimana menumbuhkan jiwa kewirausahaan berdasarkan perencanaan, bukan berdasarkan kebetulan.

Salah satu langkah yang dilakukan untuk mengatasi masalah tersebut yaitu dengan cara menumbuh kembangkan jiwa kewirausahaan mahasiswa di perguruan tinggi. Beberapa langkah yang diambil oleh perguruan tinggi berupa diadakannya kuliah kewirausahaan dan kegiatan di luar kuliah seperti seminar/workshop kewirausahaan, praktik kewirausahaan mahasiswa, serta mengembangkan lembaga seperti pusat studi. Lembaga ini dipergunakan untuk mengembangkan kewirausahaan di perguruan tinggi. Dengan demikian perguruan tinggi diharapkan mampu untuk memotivasi mahasiswa untuk merubah cara berfikir/budaya dari paradigma pencari kerja menuju pencipta kerja.

Menurut Suryana (2009: 2) bahwa "Entrepreneurship are not only born but also made" artinya kewirausahaan tidak hanya bakat bawaan sejak lahir atau urusan pengalaman lapangan, tetapi juga dapat dipelajari dan diajarkan.Oleh karena itu, untuk menjadi wirausaha yang sukses, memiliki bakat saja tidak cukup, tetapi juga harus memiliki pengetahuan segala aspek usaha yang akan ditekuninya dalam proses pendidikan kewirausahaan.

Pengaruh pendidikan kewirausahaan selama ini telah dipertimbangkan sebagai salah satu faktor penting untuk menumbuhkan dan mengembangkan hasrat, jiwa dan perilaku berwirausaha di kalangan generasi muda Kourilsky dan Walstad dalam Achadiyah dan Irafami (2013: 163). Terkait dengan pengaruh pendidikan kewirausahaan tersebut, diperlukan adanya pemahaman tentang bagaimana mengembangkan dan mendorong lahirnya wirausahawirausaha muda yang potensial sementara mereka berada di bangku sekolah. Beberapa penelitian sebelumnya menyebutkan bahwa keinginan berwirausaha para mahasiswa merupakan sumber bagi lahirnya wirausaha-wirausaha masa depan Gorman et.al. dalam Achadiyah dan Irafami (2013: 163); Kourilsky dan Walstad dalam Achadiyah dan Irafami (2013: 163). Sikap, 
perilaku, dan pengetahuan mereka tentang kewirausahaan akan membentuk kecenderungan mereka untuk membuka usaha-usaha baru di masa mendatang.

Kewirausahaan merupakan sebuah ide yang telah menyebar luas terutama di kalangan kaum muda. Mahasiswa sebagai bagian dari kaum muda, yang memiliki tempat khusus dalam pengembangan wirausaha. Sebagian besar ajang kompetisi wirausaha muda diperuntukkan dan dimenangkan oleh mahasiswa atau mantan mahasiswa. Posisi strategis mahasiswa dalam kewirausahaan dapat terlihat dalam sifatnya sebagai pekerja keras, penuh semangat, mampu bekerja, cerdas serta berpengetahuan luas. Modal inilah yang diharapkan mampu menggerakkan wirausaha menjadi gaya hidup mahasiswa, tidak hanya sebagai tren musiman saja.

Faktor ekstrinsik merupakan faktor-faktor yang mempengaruhi individu karena pengaruh rangsangan dari luar. Faktor-faktor ekstrinsik yang mempengaruhi perilaku berwirausaha antara lain: lingkungan keluarga, lingkungan masyarakat, lingkungan kampus, lingkungan teknologi, dan peluang. Lingkungan keluarga adalah kelompok masyarakat terkecil yang terdiri dari ayah, ibu, anak, dan anggota keluarga yang lain (Paulina, 2011: 8). Keluarga merupakan dasar bagi pertumbuhan dan perkembangan anak, disinilah yang memberikan pengaruh awal terhadap terbentuknya kepribadian. Rasa tanggung jawab dan kreativitas dapat ditumbuhkan sedini mungkin sejak anak mulai berinteraksi dengan orang dewasa. Orangtua adalah pihak yang bertanggung jawab penuh dalam proses ini. Anak harus diajarkan untuk memotivasi diri untuk bekerja keras, diberi kesempatan untuk bertanggung jawab atas apa yang dia lakukan. Salah satu unsur kepribadian adalah minat. Minat berwirausaha akan terbentuk apabila keluarga memberikan pengaruh positif terhadap minat tersebut, karena sikap dan aktifitas sesama anggota keluarga saling mempengaruhi baik secara langsung maupun tidak langsung. Seharusnya orang tua yang berwirausaha dalam bidang tertentu dapat menimbulkan minat anaknya untuk berwirausaha dalam yang sama pula.

Kewirausahaan yang tumbuh dalam suatu keluarga atau kelompok masyarakat merupakan suatu aset yang sangat berharga bagi bangsa Indonesia karena akan sangat membantu perekonomian Indonesia yang masih 
belum stabil. Masyarakat masih banyak yang berpendapat bahwa untuk memulai usaha dibutuhkan modal yang tidak sedikit, kebutuhan akan modal yang banyak ditepis oleh para wirausahawan. Para wirausahawan yang telah berhasil menyatakan bahwa berwirausaha tidak selalu harus dimulai dengan modal yang besar. Bisa dimulai dengan usaha kecil maupun menengah yang ternyata juga mampu memberi sumbangan yang besar pada perekonomian Indonesia.

Akar permasalahan dari tingginya angka pengangguran ditingkat pendidikan tinggi ini antara lain adalah paradigma berfikir lulusan yang masih berorientasi pada pencari kerja. Mayoritas lulusan perguruan tinggi lebih memilih bekerja sebagai buruh/karyawan/pekerja yang dibayar oleh suatu instansi tertentu dibandingkan bekerja mandiri dan mempekerjakan orang lain/wirausaha. Akar permasalahan yang lain adalah kompetensi lulusan yang tidak sesuai dengan permintaan industri. Banyak dari perusahaan lebih mengutamakan kemampuan soft skill daripada Indeks Prestasi yang tinggi. Pengusaha membutuhkan tenaga kerja yang inovatif, kreatif, memiliki jiwa kepemimpinan yang kuat, komunikatif, dan lain sebagainya.

\section{Tabel 1}

Penelitian Terdahulu

\begin{tabular}{|c|c|c|c|c|c|}
\hline \multirow{2}{*}{ No. } & \multirow{2}{*}{ Penulis } & \multirow{2}{*}{ Judul } & \multicolumn{2}{|c|}{ Variabel } & \multirow{2}{*}{ Hasil } \\
\hline & & & Independent & Dependent & \\
\hline 1. & $\begin{array}{l}\text { Andwiani } \\
\text { Sinarasri, Ayu } \\
\text { Noviani } \\
\text { Hanum }\end{array}$ & $\begin{array}{l}\text { Pengaruh Latar } \\
\text { Belakang Pendidikan } \\
\text { Terhadap Motivasi } \\
\text { Kewirausahaan } \\
\text { Mahasiswa }\end{array}$ & $\begin{array}{l}\text { Latar belakang } \\
\text { pendidikan }\end{array}$ & $\begin{array}{l}\text { Motivasi } \\
\text { kewirausahaa } \\
\text { n mahasiswa }\end{array}$ & $\begin{array}{l}\text { Latar belakang } \\
\text { individu berpengaruh } \\
\text { positif terhadap } \\
\text { motivasi } \\
\text { kewirausahaan } \\
\text { mahasiswa }\end{array}$ \\
\hline 2. & $\begin{array}{l}\text { Retno Budi } \\
\text { Lestari dan } \\
\text { Trisnadi } \\
\text { Wijaya }\end{array}$ & $\begin{array}{l}\text { Pengaruh Pendidikan } \\
\text { Kewirausahaan } \\
\text { Terhadap Minat } \\
\text { Berwirausaha } \\
\text { Mahasiswa di STIE } \\
\text { MDP, STMIK MDP, } \\
\text { dan STIE MUSI }\end{array}$ & $\begin{array}{l}\text { Pendidikan } \\
\text { kewirausahaan }\end{array}$ & $\begin{array}{l}\text { Minat } \\
\text { berwirausaha } \\
\text { mahasiswa }\end{array}$ & $\begin{array}{l}\text { Pendidikan } \\
\text { kewirausahaan } \\
\text { berpengaruh positif } \\
\text { terhadap minat } \\
\text { berwirausaha } \\
\text { mahasiswa }\end{array}$ \\
\hline 3. & $\begin{array}{l}\text { Dian Mega } \\
\text { Maharani }\end{array}$ & $\begin{array}{l}\text { Perilaku } \\
\text { Kewirausahaan } \\
\text { Pedagang Etnis Cina } \\
\text { dan Pedagang Etnis } \\
\text { Jawa di Pasar Yaik } \\
\text { Permai Semarang }\end{array}$ & $\begin{array}{l}\text { Perilaku } \\
\text { kewirausahaan }\end{array}$ & $\begin{array}{l}\text { 1. Pedagang } \\
\text { Etnis Cina } \\
\text { 2. Pedagang } \\
\text { Etnis Jawa. }\end{array}$ & $\begin{array}{l}\text { Terdapat perbedaan } \\
\text { yang signifikan antara } \\
\text { Perilaku } \\
\text { Kewirausahaan pada } \\
\text { Pedagang Etnis Cina } \\
\text { dan Pedagang Etnis } \\
\text { Jawa. }\end{array}$ \\
\hline
\end{tabular}




\begin{tabular}{|c|c|c|c|c|c|}
\hline \multirow{2}{*}{ No. } & \multirow{2}{*}{ Penulis } & \multirow{2}{*}{ Judul } & \multicolumn{2}{|c|}{ Variabel } & \multirow{2}{*}{ Hasil } \\
\hline & & & Independent & Dependent & \\
\hline 4. & $\begin{array}{l}\text { Nopalia, } \\
\text { Wirmie Eka } \\
\text { Putra, Dewi } \\
\text { Fitriani }\end{array}$ & $\begin{array}{l}\text { Pengaruh } \\
\text { Penggunaan } \\
\text { Informasi Akuntansi } \\
\text { Manajemen dan } \\
\text { Kepribadian } \\
\text { Wirausaha Terhadap } \\
\text { Kinerja Manajerial }\end{array}$ & $\begin{array}{l}\text { 1. Penggun- } \\
\text { aan } \\
\text { informasi } \\
\text { akuntansi } \\
\text { manajemen } \\
\text { 2. Kepribadian } \\
\text { wirausaha }\end{array}$ & $\begin{array}{l}\text { Kinerja } \\
\text { manajerial }\end{array}$ & $\begin{array}{l}\text { 1. Penggunaan } \\
\text { informasi } \\
\text { akuntansi } \\
\text { manajemen } \\
\text { berpengaruh positif } \\
\text { terhadap kinerja } \\
\text { manajerial } \\
\text { 2. Kepribadian } \\
\text { wirausaha } \\
\text { berpengaruh positif } \\
\text { terhadap kinerja } \\
\text { manajerial }\end{array}$ \\
\hline 5. & $\begin{array}{l}\text { Dewi Masitah } \\
\text { dan M. Edwar }\end{array}$ & $\begin{array}{l}\text { Pengaruh Peran } \\
\text { Keluarga dan Praktik } \\
\text { Kewirausahaan } \\
\text { Dalam Membentuk } \\
\text { Sikap } \\
\text { Kewirausahaan } \\
\text { Mahasiswa }\end{array}$ & $\begin{array}{l}\text { 1. Peran } \\
\text { keluarga } \\
\text { 2. Praktik } \\
\text { kewirausaha } \\
\text { an }\end{array}$ & $\begin{array}{l}\text { Sikap kewira- } \\
\text { usahaan }\end{array}$ & $\begin{array}{l}\text { 1. Peran keluarga } \\
\text { berpengaruh positif } \\
\text { terhadap sikap } \\
\text { kewirausahaan } \\
\text { 2. Praktik } \\
\text { kewirausahaan } \\
\text { berpengaruh positif } \\
\text { terhadap sikap } \\
\text { kewirausahaan }\end{array}$ \\
\hline 6. & $\begin{array}{l}\text { Hanum Risfi } \\
\text { Mahanani }\end{array}$ & $\begin{array}{l}\text { Analisis Pengaruh } \\
\text { Faktor Internal Dan } \\
\text { Faktor Lingkungan } \\
\text { Eksternal Terhadap } \\
\text { Minat Berwirausaha }\end{array}$ & $\begin{array}{l}\text { 1. Faktor } \\
\text { internal } \\
\text { lingkungan } \\
\text { 2. Faktor } \\
\text { ekternal } \\
\text { lingkungan }\end{array}$ & $\begin{array}{l}\text { Minat ber- } \\
\text { wirausaha }\end{array}$ & $\begin{array}{l}\text { 1. Faktor internal } \\
\text { lingkungan } \\
\text { berpengaruh positif } \\
\text { terhadap minat } \\
\text { wirausaha } \\
\text { 2. Faktor eksternal } \\
\text { lingkungan } \\
\text { berpengaruh positif } \\
\text { terhadap minat } \\
\text { berwirausaha }\end{array}$ \\
\hline
\end{tabular}

\section{Landasan Teori}

Anoraga (2007: 28) menjelaskan bahwa kewirausahaan merupakan suatu profesi yang timbul karena interaksi antara ilmu pengetahuan yang diperoleh dari pendidikan formal dengan seni yang hanya dapat diperoleh dari suatu rangkaian kerja yang didapat dalam praktik.

Pendidikan wirausaha dianggap sebagai faktor penunjang keberhasilan dalam menjalankan suatu usaha. Pendidikan memberikan bekal berupa pengetahuan dan keterampilan yang dibutuhkan oleh wirausahawan. Menurut Suprapto dalam Zuchdi (2008: 7) menjelaskan keterampilan berpikir kreatif, yaitu keterampilan individu dalam menggunakan proses berpikirnya untuk menghasilkan suatu ide yang baru, konstruktif, dan baik berdasarkan konsepkonsep yang rasional, pesepsi, dan intuisi individu. Dalam kaitannya dengan pendidikan kewirausahaan keterampilan berpikir kreatif sangat diperlukan 
dalam keberlangsungan sebuah usaha.

Nilai-nilai yang dikembangkan dalam pendidikan kewirausahaan adalah pengembangan nilai-nilai dan ciri-ciri wirausaha.

Tabel 2

Nilai-Nilai Pokok dan Deskripsi Pendidikan Kewirausahaan

\begin{tabular}{cll}
\hline No. & \multicolumn{1}{c}{ Nilai } & \multicolumn{1}{c}{ Deskripsi } \\
\hline 1. & Mandiri & $\begin{array}{l}\text { Sikap dan perilaku yang tidak mudah tergantung } \\
\text { pada orang lain dalam menyelesaikan tugas-tugas. }\end{array}$ \\
\hline 2. & Kreatif & $\begin{array}{l}\text { Berfikir dan melakukan sesuatu untuk } \\
\text { menghasilkan sesuatu hal yang baru atau } \\
\text { memodifikasi produk/jasa yang telah ada. }\end{array}$ \\
\hline 3. & $\begin{array}{l}\text { Berani } \\
\text { mengambil resiko }\end{array}$ & $\begin{array}{l}\text { Kemampuan seseorang untuk melaksanakan } \\
\text { pekerjaan yang menantang, berani mengambil } \\
\text { resiko kerja. }\end{array}$ \\
\hline 4. & $\begin{array}{l}\text { Berorientasi pada } \\
\text { tindakan }\end{array}$ & $\begin{array}{l}\text { Mengambil inisiatif untuk bertindak dan bukan } \\
\text { menunggu sebelum sebuah kejadian yang tidak } \\
\text { dikehendaki terjadi. }\end{array}$ \\
\hline 5. & Kepemimpinan & $\begin{array}{l}\text { Sikap dan perilaku seseorang yang selalu terbuka } \\
\text { terhadap saran dan kritik, mudah bergaul dan kerja } \\
\text { sama. }\end{array}$ \\
\hline 6. & Kerja keras & $\begin{array}{l}\text { Perilaku yang menunjukkan upaya sungguh- } \\
\text { sungguhdalammenyelesaikan tugas dan mengatasi } \\
\text { berbagai hambatan. }\end{array}$ \\
\hline
\end{tabular}

Sumber: Kemendiknas dalam Astiti (2014: 26)

\section{Lingkungan}

Lingkungan menurut Sartain (ahli psikologi Amerika) meliputi kondisidan alam dunia ini yang dengan cara-cara tertentu mempengaruhi tingkah laku, pertumbuhan dan perkembangan manusia (life processes) (Maharani, 2014: 33). Sedangkan menurut Putri dalam Mahanani (2014: 33) lingkungan (environment) dalam lingkup yang luas memiliki arti sesuatu yang bersifat fisik dan non fisik yang mempengaruhi kehidupan seseorang.

Faktor-faktor ekstrinsik yang mempengaruhi minat berwirausaha antara lain: lingkungan sosial dan keluarga, lingkungan sekolah, lingkungan teknologi Yuriski dan Machmudun dalam Mahanani (2014: 34). 
Keluarga merupakan lingkungan sosial terdekat dari seorang wirausaha, yang sangat besar peranannya dalam membentuk karak-ter, termasuk karakter wirausaha dari seorang anak. Menurut Saroni dalam Marini (2014: 199) mengatakan bahwa ling-kungan keluarga mempunyai andil yang sangat besar dalam mempersiapkan anak-anak men-jadi seorang wirausahawan di masa yang akan datang. Pada lingkungan keluarga tersebut, seorang anak mendapat inspirasi dan dukungan berwi-rausaha dari keluarga, dan terdapat kegiatan dalam keluarga tersebut yang bermakna belajar kewirausahaan.

Lingkungan Masyarakat merupakan lingkungan di luar lingkungan keluarga baik di kawasan tempat tinggalnya maupun dikawasan lain. Masyarakat dapat mempengaruhi seseorang untuk berperilaku seperti wirausaha dalam bidang fashion antara lain; tetangga, saudara, teman, kenalan, dan orang lain. Misalnya : seseorang yang tinggal didaerah yang terdapat usaha fashion atau sering bergaul dengan pengusaha fashion yang berhasil akan menimbulkan minat berwirausaha bidang fashion pula.

Pendidikan di universitas merupakan tanggung jawab dosen. Sebagai pendidik dalam lembaga pendidikan formal, maka dosen berperan untuk mencerdaskan kehidupan bangsa, apalagi yang dibutuhkan orang pada dasarnya adalah ke arah pengembangan kualitas SDM (Sumber Daya Manusia) yang berguna dalam kehidupannya. Faktor-faktor tersebut dapat mempengaruhi besarnya keinginan yang timbul dari dalam maupun luar diri mahasiswa terhadap sesuatu yaitu perilaku kewirausahaan. Lingkungan kampus memiliki arti yang sama dengan lingkungan pendidikan.

Pendidikan di universitas saat ini ditunt ut tidak hanya mampu menghasilkan lulusan semata, pendidikan juga harus memiliki orientasi yang jelas kearah mana lulusan akan berkontribusi dimasyarakat. Untuk menanamkan wirausaha di universitas maka peran dan keaktifan dosen dalam mengajar harus menarik, misalnya pembawaan yang ramah dan murah senyum, lucu, mendatangkan wirausahawan untuk memberikan cerita tentang keberhasilan dan kegagalannya sehingga akhirnya bisa berhasil. Selain itu peran aktif para mahasiswa juga dituntut karena sasaran pengajaran ini adalah keberhasilan mahasiswa bukan keberhasilan dosen. 
Di sisi lain, saat ini semakin canggih dunia teknologi, semakin canggih pula cara orang menyampaikan informasi. Dengan adanya informasi yang semakin mudah didapatkan. Kemajuan teknologi saat ini tidak bisa dipisahkan dari kehidupan masyarakat. Berbagai informasi yang terjadi di berbagai belahan dunia kini bisa langsung diketahui berkat kemajuan teknologi (globalisasi). Kemajuan teknologi ini menyebabkan perubahan yang begitu besar pada kehidupan umat manusia dengan segala peradaban dan kebudayaannya. Perubahan ini juga memberikan dampak yang begitu besar terhadap transformasi nilai-nilai yang ada di masyarakat. Kemajuan teknologi seperti televisi, telepon dan telepon genggam (HP), bahkan internet. Saat ini dapat kita lihat betapa kemajuan teknologi telah mempengaruhi gaya hidup dan pola pikir masyarakat, terutama di kalangan remaja Ibnu dalam Mahanani (2014: 39-40).

Menurut Suhartanto dalam Mahanani (2014: 40) memodelkan bisnis berbasis teknologi dalam sebuah proses bisnis. Pendiri google menggunakan teknologi untuk menciptakan nilai (value) dan menyampaikannya kepada konsumen. Value tersebut akhirnya membawa nilai ekonomi.

Dapat ditarik kesimpulan bahwa kecanggihan teknologi dapat mempengaruhi gaya hidup seseorang. Adanya internet dapat membantu menyampaikan informasi lebih cepat, dengan begitu banyak pengusaha yang dapat memanfaatkan teknologi untuk berbisnis dan dengan adanya internet mempermudah siapa saja untuk melakukan kegiatan bisnis dengan contoh kecil berjualan melalui internet atau sosial media.

\section{Kepribadian}

Kepribadian adalah ciri atau karakteristik atau gaya atau sifat khas dari diri seseorang yang bersumber dari bentukan-bentukan yang diterima dari lingkungan (Sjarkawi, 2006: 11). Sedangkan menurut Yusuf (2008: 5) menjelaskan bahwa kepribadian merupakan seperangkat asumsi tentang kualitas tingkah laku manusia beserta definisi empirisnya.

Menurut Anoraga (2009: 1) kepribadian seseorang mempengaruhi dirinya dalam memilih pekerjaan. Hal tersebut didukung oleh pernyataan Holland, menurut Holland yang diterjemahkan oleh Sukardi (2004: 7) 
menjelaskan bahwa seseorang akan merasa nyaman dalam bekerja apabila pekerjaan tersebut sesuai dengan kepribadian.

Salah satu faktor yang dianggap mempengaruhi kepribadian yaitu tingkat inteligensi individu. Tingkat intelegensi dapat mempengaruhi perkembangan kepribadian seseorang. Individu yang inteligensinya tinggi atau normal biasa mampu menyesuaikan diri dengan lingkungannya secara wajar, sedangkan yang rendah biasanya sering mengalami hambatan atau kendala dalam menyesuaikan diri dengan lingkungannya.

Menurut Marbun dalam Alma (2011: 52-57) dalam penelitiannya di Amerika Serikat menyebutkan bahwa sifat yang harus dimiliki seorang wirausahawan adalah (1) percaya diri, (2) berorientasi pada tugas dan hasil, (3) pengambilan risiko, (4) kepemimpinan, (5) keorisinilan, dan (6) berorientasi ke masa depan.

\section{Perilaku Kewirausahaan}

Perilaku adalah suatu respons terhadap stimulus yang diterimanya (Walgito, 2002: 10). Perilaku manusia dalam kaitannya dengan lingkungan merupakan tinjauan dari antropologi. Antropologi, khususnya antropologi budaya meninjau perilaku manusia itu tidak dapat lepas dari segi kebudayaan yang melatarbelakanginya (Walgito, 2002: 10).

Kata entrepreneur atau wirausaha dalam bahasa Indonesia merupakan gabungan dari wira berarti gagah, berani, perkasa dan usaha berarti bisnis sehingga istilah entrepreneur dapat diartikan sebagai orang yang berani atau perkasa dalam usaha atau bisnis (Riyanti, 2003: 2).

Kaitannya dengan perilaku wirausaha, menurut Suryana (2003: 1) mengatakan bahwa kewirausahaana dalah kemampuan kreatif dan inovatif yang dijadikan dasar, kiat, dan sumber daya untuk mencari peluang menuju sukses. Kewirausahaan adalah kemampuan untuk menciptakan sesuatu yang baru dan berbeda (create new and different) melalui berpikir kreatif dan bertindak inovatif untuk menciptakan peluang.

Menurut Riyanti (2003: 25) menyimpulkan wirausaha adalah orang yang menciptakan kerja bagi orang lain dengan cara mendirikan, mengembangkan, dan melembagakan perusahaan miliknya sendiri dan bersedia 
mengambil resiko pribadi dalam menemukan peluang berusaha dan secara kreatif menggunakan potensi-potensi dirinya untuk mengenali produk, mengelola dan menemukan cara produksi, menyusun operasi untuk pengadaan produk, memasarkannya serta mengatur permodalan operasinya.

Wirausaha adalah orang-orang yang mempunyai kemampuan melihat dan menilai kesempatan-kesempatan bisnis, mengumpulkan sumber daya yang dibutuhkan guna mengambil keuntungan daripadanya serta mengambil tindakan yang tepat, guna memastikan kesuksesan menurut Geoffrey G. Meredith dalam Anoraga (2002: 137).

Berdasarkan beberapa pendapat diatas mengenai perilaku dan kewirausahaan maka dapat disimpulkan bahwa perilaku kewirausahaan adalah reaksi maupun respon positif yang dilakukan oleh individu untuk menciptakan suatu bentuk usaha baru (baik barang maupun jasa) melalui cara-cara yang mandiri, kreatif, inovatif, kerja keras bahkan beresiko agar memperoleh keuntungan supaya kebutuhan hidupnya terpenuhi.

Menurut Timmons dalam Maharani (2013: 21-23) faktor yang harus dimiliki oleh setiap wirausahawan untuk mencapai keberhasilan dalam berwirausaha antara lain:

1. Komitmen dan determinasi, komitmen dan determinasi adalah faktor yang paling penting dibandingkan dengan faktor yang lainnya. Faktor komitmen dan determinasi ini membuat wirausahawan dapat mengatasi hambatan yang ditemui dan dapat menutupi kelemahan dan kekurangannya dalam berwirausaha. Wirausahawan yang sukses memiliki keberanian, disiplin kerja yang tinggi, kerja keras dalam usahanya dan tahan terhadap kesulitan.

2. Kepemimpinan, untuk menjadi wirausahawan yang sukses dibutuhkan banyak pengalaman dalam berwirausaha, pengetahuan yang baik tehadap pasar, memiliki keterampilan dalam mengatur strategi berwirausaha.

3. Ambisi untuk mencari peluang, wirausaha yang berhasil adalah yang selalu memanfaatkan peluang yang ada.

4. Menerima resiko, kebimbangan, dan ketidaktentuan, wirausahawan yang berhasil bukanlah seorang penjudi yang mengambil keputusan bisnis sesuka mereka. Akan tetapi wirausaha yang berhasil adalah mereka yang membuat keputusan dengan mempertimbangkan resiko berwirausaha. 
Wirausahawan yang berhasil juga nyaman dan tahan terhadap ketidakpastian bisnis.

5. Kreativitas, percaya diri, dan kemampuan beradaptasi, wirausahawan yang berhasil selalu percaya terhadap kemampuan dirinya sendiri. Wirausahawan tidak takut terhadap kegagalan dan selalu berusaha untuk mencapai keberhasilan dengan melihat kenyataan yang ada. Wirausahawan sukses memiliki kemampuan untuk menjadikan kegagalan menjadi sebuah pelajaran. Pengalaman kegagalan ini membuat individu mampu mengatasi masalah yang muncul dengan mengatasi masalah yang ada menggunakan cara yang sesuai.

6. Motivasi untuk menjadi unggul, wirausahawan yang berhasil memiliki motivasi untuk menjadi unggul dan lebih baik dibandingkan dengan wirausahawan yang lain. Wirausahawan memiliki keinginan yang tinggi untuk mencapai keberhasilan, mereka memiliki kemampuan dalam memilih dan mengambil peluang dan tahu kapan waktu yang tepat untukmengatakan tidak terhadap suatu peluang.

Berdasarkan beberapa penjelasan di atas, dapat disimpulkan bahwa faktor-faktor yang mempengaruhi perilaku kewirausahaan terdiri dari faktor internal dan faktor eksternal, faktor internal yang terdiri antara lain komitmen dan determinasi, kepemimpinan, obsesi terhadap peluang, menerima resiko, kreativitas, percaya diri, dan kemampuan beradaptasi, motivasi untuk menjadi unggul, faktor fisik, faktor psikis atau kepribadian, faktor ketahanan dalam menghadapi tekanandan faktor eksternal yang mempengaruhi antara lain lingkungan keluarga, lingkungan sosial, dan etnis, di mana kondisi lingkungan keluarga pada tiap-tiap etnis sangatlah berbeda, lokasi wirausaha, pendidikan. 


\section{Kerangka Pemikiran}

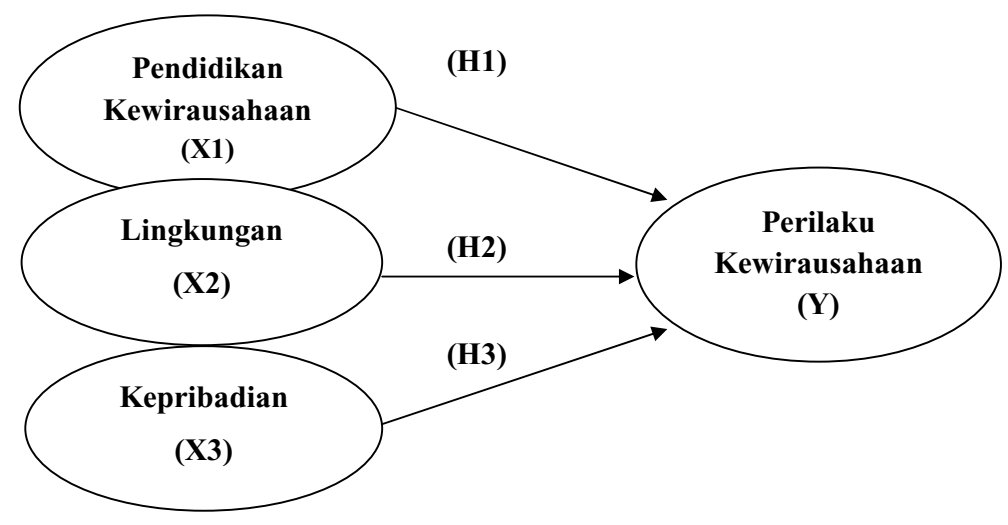

Gambar 1

Kerangka Pemikiran

\section{Hipotesis}

Hipotesis menurut Sugiyono (2009: 96) adalah jawaban sementara terhadap rumusan penelitian di mana rumusan masalah penelitian telah dinyatakan dalam bentuk kalimat pernyataan. Hipotesis dalam penelitian ini adalah sebagai berikut:

H1 : Pendidikan kewirausahaan berpengaruh positif dan signifikan terhadap perilaku kewirausahaan

H2 : Lingkungan berpengaruh positif dan signifikan terhadap perilaku kewirausahaan

H3 : Kepribadian berpengaruh positif dan signifikan terhadap perilaku kewirausahaan

\section{Metode Penelitian}

Jenis penelitian yang dilakukan dalam penelitian ini adalah penelitian kuantitatif. Penelitian kuantitatif adalah penelitian yang dilakukan dengan mengumpulkan data berupa angka yang kemudian data tersebut diolah dan dianalisis untuk mendapatkan suatu informasi ilmiah dibalik angka-angka tersebut (Martono, 2011:20). 


\section{Objek Penelitian}

Penelitian ini dilakukan pada Jurusan Pebankan Syariah S-1 Fakultas Ekonomi dan Bisnis Islam di IAIN Salatiga. Waktu yang dibutuhkan untuk mendapatkan data dalam penelitian ini adalah selama 1 hari dimulai dari tanggal 4 Maret 2016.

Populasi penelitian ini adalah mahasiswa Jurusan Perbankan Syariah S-1 di IAIN Salatiga angkatan 2012. Dimana jumlah mahasiswa aktif Perbankan Syariah S-1 adalah 103 mahasiswa, sehingga total populasi adalah 103 mahasiswa.

Menurut Bawono (2006: 28), sampel adalah objek atau subjek penelitian yang dipilih guna mewakili keseluruhan dari populasi. Hal ini dilakukan untuk menghemat waktu dan biaya. Sehingga didalam menentukan sampel harus berhati-hati, karena kesimpulan yang dihasilkan, nantinya merupakan kesimpulan dari populasi. Adapun teknik untuk menentukan jumlah sampel, dapat menggunakan rumus sebagai berikut :

$$
\begin{aligned}
& s=\frac{P}{\left(P . \mathrm{e}^{2}\right)+1} \\
& s=\frac{103}{103(0,1)^{2}+1} \\
& s=\frac{103}{2,03} \\
& s=50,73=50
\end{aligned}
$$

Keterangan:

$s$ : Jumlah sampel yang dicari

$P$ : Jumlah populasi

e : error atau tingkat kesalahan yang diyakini

Jadi jumlah sampel dalam penelitian ini adalah 50 mahasiswa Perbankan Syariah di IAIN Salatiga, dengan menggunakan tingkat kesalahan yang diyakini sebesar $10 \%$. 


\section{Definisi Operasional}

Definisi operasional adalah unsur penelitian yang memberitahukan bagaimana caranya mengukur suatu variabel, sehingga peneliti dapat mengetahui baik buruknya pengukuran tersebut. Adapun definisi operasional dalam penelitian ini adalah:

Tabel 3

Definisi Operasional Penelitian

\begin{tabular}{|c|c|c|c|}
\hline No. & Variabel & Indikator & Sumber \\
\hline 1. & $\begin{array}{l}\text { Pendidikan } \\
\text { kewirausahaan }\end{array}$ & $\begin{array}{l}\text { 1. Pendidikan formal } \\
\text { 2. Pendidikan non formal } \\
\text { 3. Pendidikan informal }\end{array}$ & $\begin{array}{l}\text { Undang-Undang Republik } \\
\text { Indonesia No. } 2 \text { Tahun } 2003 \\
\text { pasal } 13 \text { ayat } 1 .\end{array}$ \\
\hline 2. & Lingkungan & $\begin{array}{l}\text { 1. Lingkungan keluarga } \\
\text { 2. Lingkungan masyarakat } \\
\text { 3. Lingkungan sekolah } \\
\text { 4. Lingkungan teknologi }\end{array}$ & $\begin{array}{l}\text { Mahanani (2014: 34) dan } \\
\text { Paulina (2011: 35) }\end{array}$ \\
\hline 3. & Kepribadian & $\begin{array}{l}\text { 1. Kepercayaan kepada diri sendiri } \\
\text { 2. Ketahanan menghadapi cobaan } \\
\text { 3. Berani dalam mengambil risiko } \\
\text { 4. Kepemimpinan } \\
\text { 5. Berorientasi ke masa depan }\end{array}$ & Citradewi (2015: 33) \\
\hline & $\begin{array}{l}\text { Perilaku } \\
\text { kewirausahaan }\end{array}$ & $\begin{array}{l}\text { 1. Mau dan suka bekerja keras } \\
\text { 2. Berani mengambil resiko yang } \\
\text { diperhitungkan } \\
\text { 3. Percaya terhadap diri sendiri dan } \\
\text { mandiri } \\
\text { 4. Bertanggung jawab } \\
\text { 5. Mudah bergaul dan hangat } \\
\text { dalam berkomunikasi } \\
\text { 6. Berorientasi pada masa depan } \\
\text { 7. Menilai prestasi lebih tinggi dari } \\
\text { pada uang. }\end{array}$ & Riyanti (2003:33) \\
\hline
\end{tabular}

\section{Hasil Penelitian}

Tabel 4

Hasil Uji Reliabilitas

\begin{tabular}{lcc}
\hline \multicolumn{1}{c}{ Variabel } & Cronbach Alpha & Kesimpulan \\
\hline Pendidikan Kewirausahaan & 0,662 & Reliabel \\
Lingkungan & 0,711 & Reliabel \\
Kepribadian & 0,849 & Reliabel \\
Perilaku Kewirausahaan & 0,875 & Reliabel \\
\hline
\end{tabular}

Sumber: Data Primer yang diolah (2016) 
Tabel di atas menunjukkan bahwa semua variabel yang digunakan nilainya lebih besar dari 0,6 . Itu berarti kuesioner yang digunakan handal (realibel).

\section{Tabel 5}

Hasil Uji Validitas

\begin{tabular}{lccc}
\hline \multicolumn{1}{c}{ Variabel } & $\begin{array}{c}\text { Pearson } \\
\text { Corelation }\end{array}$ & $\begin{array}{c}\text { Significant } \\
(\mathbf{2} \text { Tailed) }\end{array}$ & Kesimpulan \\
\hline Pendidikan Kewirausahaan & $0,298^{*}-0,748^{* *}$ & .000 & Valid \\
Lingkungan & $0,321^{*}-0,726^{* *}$ & .000 & Valid \\
Kepribadian & $0,291^{*}-0,789^{* *}$ & .000 & Valid \\
Perilaku Kewirausahaan & $0,283^{*}-0,736^{* *}$ & .000 & Valid \\
\hline
\end{tabular}

Sumber: Data Primer diolah (2016)

Dari tabel di atas, diketahui semua pertanyaan dari masing variabel nilainya menghasilkan tanda bintang, baik bertanda bintang satu atau dua. Jadi semua pertanyaan yang digunakan dalam penelitian sudah secara tepat mengungkapkan variabel - variabelnya.

Tabel 6

Uji secara Individu ( $\mathrm{Uji}_{\mathrm{test}}$

\begin{tabular}{|c|c|c|c|c|}
\hline Variabel & Nilai $t_{\text {test }}$ & $\begin{array}{l}\text { Nilai } \\
\mathrm{T}_{\text {tabel }}\end{array}$ & $\begin{array}{l}\text { Nilai } \\
\text { Sig. }\end{array}$ & Keterangan \\
\hline Contant & 2,595 & \multirow{4}{*}{1,298} & 0,013 & Signifikan \\
\hline $\begin{array}{l}\text { Pendidikan } \\
\text { kewirausahaan }\end{array}$ & 3,057 & & 0,004 & Signifikan \\
\hline Lingkungan & $-1,456$ & & 0,152 & Tidak Signifikan \\
\hline Kepribadian & 4,224 & & 0,000 & Signifikan \\
\hline F-test & 23,182 & & 0,000 & Signifikan \\
\hline R square & 0,576 & & & \\
\hline
\end{tabular}

Sumber: data primer yang diolah (2015)

Berdasarkan tabel di atas, terlihat bahwa variabel independen yang berpengaruh secara signifikan terhadap variabel dependen berjumlah 2 variabel saja dari total 3 variabel independen yang digunakan.

Nilai $t_{\text {test }}$ variabel pendidikan kewirausahaan dengan skor 3,057 ternyata lebih dari nilai $t_{\text {tabel }}$ yang mempunyai nilai 1,298. Dengan demikian, dapat disimpulkan bahwa variabel pendidikan kewirausahaan berpengaruh secara signifikan terhadap perilaku kewirausahaan. hal ini juga didukung 
oleh nilai nilai sig. $0,004<0,05$.

Nilai $t_{\text {test }}$ variabel lingkungan dengan skor -1,456 ternyata lebih besar dari nilai $t_{\text {tabel }}$ yang mempunyai nilai 1,298. Dengan demikian, dapat disimpulkan bahwa variabel lingkungan tidak berpengaruh secara signifikan terhadap perilaku kewirausahaan. hal ini juga didukung oleh nilai nilai sig. $0,152>0,05$.

Nilai $t_{\text {test }}$ variabel kepribadian dengan skor 4,224 ternyata lebih besar dari nilai $t_{\text {tabel }}$ yang mempunyai nilai 1,298. Dengan demikian, dapat disimpulkan bahwa variabel kepribadian berpengaruh secara signifikan terhadap perilaku kewirausahaan. hal ini juga didukung oleh nilai nilai sig. $.000<0,05$. Dari beberapa penjelasan di atas dapat ditarik kesimpulan bahwa variabel yang paling dominan mempengaruhi perilaku kewirausahaan adalah variabel kepribadian (X3), yang ditunjukkan dengan nilai $t_{\text {hitung }}$ sebesar 4,224.

Uji F ini hampir sama dengan uji $t_{\text {test }}$. Yang membedakan adalah untuk melihat tingkat signifikansi, variabel independen tidak secara individu mempengaruhi variabel dependen, melainkan secara bersama-sama. Artinya dengan tingkat kepercayaan tertentu, variabel independen mempengaruhi variabel dependen secara serentak atau bersama-sama.

Berdasarkan tabel di atas terlihat nilai $\mathrm{F}_{\text {hitung }}$ sebesar 23,182. Sedangkan nilai $F_{\text {tabel }}$ sebesar 2,790. Hal ini berarti variabel independen secara bersama-sama mempengaruhi variabel dependen secara signifikan karena nilai $F_{\text {hitung }}>F_{\text {tabel. }}$ Hal tersebut juga didukung dari nilai pada kolom sig. lebih kecil dari 0,05 . Dari tabel di atas juga terlihat bahwa nilai pada kolom $\mathrm{R}$ Square sebesar 0,576. Hal tersebut berarti kontribusi variabel independen terhadap variabel dependen sebesar 57\%, sedangkan sisanya sebesar $43 \%$ dipengaruhi oleh variabel lain diluar model regresi yang digunakan.

\section{Uji multicollinearity}

Uji Multicollinearity berarti menguji apakah terdapat hubungan yang sempurna antara variabel independen yang digunakan. Metode yang digunakan adalah VIF. Jika nilai VIF-nya tidak lebih besar dari 5 maka tidak terjadi Multicollinearity, jika lebih maka terdapat gejala Multicollinearity. 
Tabel 7

Uji Multicollinearity

Coefficients $^{\mathrm{a}}$

\begin{tabular}{|c|c|c|c|c|c|c|c|c|}
\hline \multirow{2}{*}{\multicolumn{2}{|c|}{ Model }} & \multicolumn{2}{|c|}{$\begin{array}{c}\text { Unstandardized } \\
\text { Coefficients }\end{array}$} & $\begin{array}{c}\text { Standardized } \\
\text { Coefficients }\end{array}$ & \multirow[t]{2}{*}{$\mathrm{t}$} & \multirow[t]{2}{*}{ Sig. } & \multicolumn{2}{|c|}{ Collinearity Statistics } \\
\hline & & B & $\begin{array}{l}\text { Std. } \\
\text { Error }\end{array}$ & Beta & & & Tolerance & VIF \\
\hline \multirow{4}{*}{1} & (Constant) & 13.330 & 5.136 & & 2.595 & .013 & & \\
\hline & $\begin{array}{l}\text { Pendidikan } \\
\text { kewirausahaan }\end{array}$ & .842 & .275 & .376 & 3.057 & .004 & .572 & 1.747 \\
\hline & Lingkungan & -.289 & .198 & -.179 & -1.456 & .152 & .571 & 1.751 \\
\hline & Kepribadian & .857 & .203 & .589 & 4.224 & .000 & .445 & 2.246 \\
\hline
\end{tabular}

a. Dependent Variable: Perilaku_Kewirausahaan

Sumber: Data Primer diolah (2016)

Dari tabel di atas pada kolom VIF semua nilainya tidak ada yang lebih besar dari 5. Itu berarti data yang digunakan tidak terdapat gejala Multicollinearity.

\section{Uji heteroscedasticity}

Uji heteroscedasticity digunakan untuk mengetahui apakah varian dari variabel pengganggu sama atau berbeda. Jika sama berarti memenuhi asumsi dalam metode regresi linear yang digunakan yaitu homocedasticity. Namun jika berbeda,itulah yang disebut dengan heteroscedasticity. Untuk mengetahui apakah suatu penelitian mengalami gejala heteroscedasticity atau tidak, dapat dideteksi dengan melihat grafik Scatterplot.

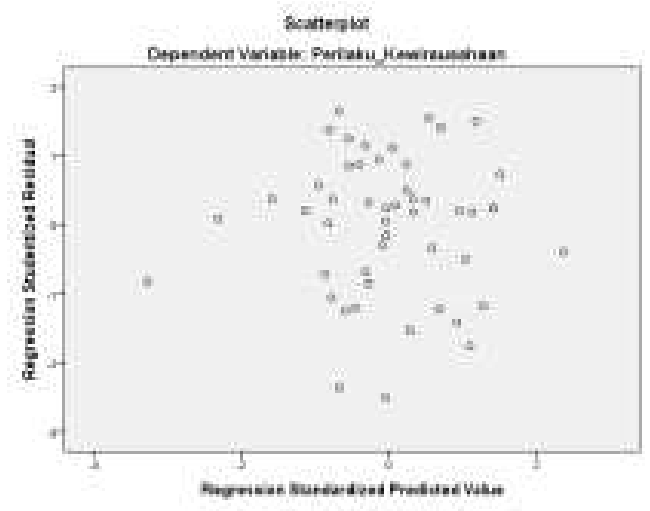

Sumber: Data Primer diolah (2016)

Gambar 2

Uji Heteroscedasticity 
Data yang tidak terkena gejala heteroscedasticity adalah jika titiktitik pola persebaran dalam grafik Scaterplot tersebar tidak beraturan dan tidak berpola.berdasarkan grafik di atas, terlihat titik-titik persebaran yang ada tersebar tidak berpola dan tidak beraturan,hal tersebut berarti data yang digunakan lolos dari gejala heteroscedasticity.

\section{Uji normality}

Uji Normality adalah pengujian terhadap model regresi yang digunakan apakah data variabel dependen dan independen yang digunakan berdistribusi normal atau tidak (Bawono, 2006). Untuk melihat apakah data yang dipakai memenuhi asumsi normality atau tidak dapat menggunakan metode analisa grafik normal plot. Asumsi yang digunakan adalah jika titiktitik persebaran dalam grafik mengikuti garis maka data yang digunakan berdistribusi normal.

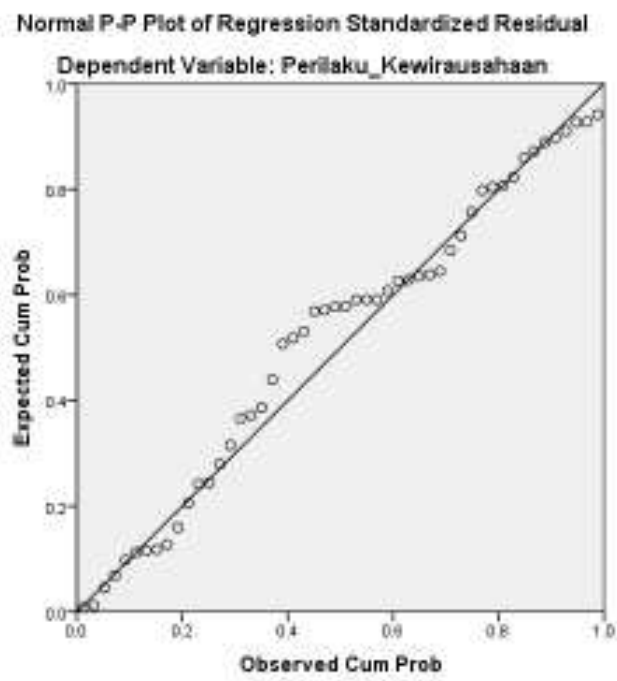

Sumber: Data Primer diolah (2016)

Gambar 3

Uji Normality

Dari tabel di atas dapat dilhat bahwa titik-titik yang ada, tersebar mengikuti alur pada garis, sehingga dapat dikatakan bahwa data yang digunakan berdistribusi secara normal. 


\section{Penutup}

Berdasarkan pembahasan analisis data mengenai faktor-faktor yang mempengaruhi perilaku kewirausahaan mahasiswa Jurusan Perbankan Syariah Fakultas Ekonomi dan Bisnis Islam IAIN Salatiga, maka penelitian menyimpulkan sebagai berikut:

1. Pendidikan kewirausahaan berpengaruh positif dan signifikan terhadap perilaku kewirausahaan mahasiswa Jurusan Perbankan Syariah Fakultas Ekonomi dan Bisnis Islam IAIN Salatiga.

2. Lingkungan berpengaruh negatif dan tidak signifikan terhadap perilaku kewirausahaan mahasiswa Jurusan Perbankan Syariah Fakultas Ekonomi dan Bisnis Islam IAIN Salatiga.

3. Kepribadian berpengaruh positif dan signifikan terhadap perilaku kewirausahaan mahasiswa Jurusan Perbankan Syariah Fakultas Ekonomi dan Bisnis Islam IAIN Salatiga.

4. Variabel yang paling dominan dalam mempengaruhi perilaku kewirausahaan mahasiswa Jurusan Perbankan Syariah Fakultas Ekonomi dan Bisnis Islam IAIN Salatiga adalah kepribadian. Teori kepribadian Holland merupakan teori yang tepat dalam perilaku kewirausahaan, hal ini dibuktikan dengan kepribadian sebagai variabel yang paling berpengaruh.

Kepribadian menjadi paling signifikan karena kepribadian memegang peranan yang sangat besar dalam beraktifitas berwirausaha. Hal ini dikarenakan kepribadian merupakan sifat yang khas yang membedakan dirinya dan orang lain yang tentunya akan berpengaruh pada kualitas karir seorang pelaku usaha.

\section{Daftar pustaka}

Alma, Buchari. 2011. Kewirausahaan. Bandung: Alfabeta.

Andini, Alfath. 2014. "Analisis Faktor-Faktor yang Memotivasi Mahasiswa Berkeinginan Menjadi Entrepreneur Muslim.” Skripsi. STAIN Salatiga.

Anoraga, P. Sudantoko. D. 2002. Koperasi, Kewirausahaan, dan Usaha Kecil. Jakarta: PT.Rineka Cipta. 
Anoraga, Pandji. 2007. Pengantar Bisnis: Pengelolaan Bisnis dalam Era Globalisasi. Jakarta: Rineka Cipta.

Anoraga, Pandji. 2009. Psikologi Kerja. Jakarta: Rineka Cipta.

Arikunto, Suharsimi. 2006. Prosedur Penelitian Suatu Pendekatan Praktik. Jakarta: PT. Rineka Cipta.

Astiti, Yunita Widyaning. 2014. "Pengaruh Pendidikan Kewirausahaan terhadap Motivasi Berwirausaha dan Keterampilan Berwirausaha Mahasiswa Pendidikan Ekonomi Universitas Negeri Yogyakarta”. Skripsi. Universitas Negeri Yogyakarta.

Bawono, Anton. 2006. Multivariate Analisys dengan SPSS. Salatiga: STAIN Salatiga Pres.

Citradewi, Adelina. 2015. "Pengaruh Kepribadian, Pendidikan Kewirausahaan, dan Lingkungan Keluarga terhadap Aktivitas Berwirausaha Mahasiswa Universitas Negeri Semarang”. Skripsi. Jurusan Pendidikan Ekonomi. Fakultas Ekonomi. Universitas Negeri Semarang.

Daryanto. 2012. Pendidikan Kewirausahaan. Yogyakarta: Gava Media.

Hanum, Ayu Noviani dan Sinarsari, Andwiani. 2012. "Pengaruh Latar Belakang Pendidikan terhadap Motivasi Kewirausahaan Mahasiswa". Jurnal. Semarang: Universitas Muhammadiyah. http:/ /jurnal.unimus.ac.id diakses 24 September 2014.

Hisrich, R.D., Peters, M.P., \& Stepeherd, D.A. (2008). Entrepreneurship. New York: The McGraw Hill Irwin.

Holland, John L. 2004. Psikologi Pemilihan Karier. Terjemahan Dewa Ketut Sukardi. Jakarta: Rineka Cipta.

Irafami,D.T, Achadiyah, B.N. 2013. "Perbandingan Intensi Kewirausahaan Mahasiswa Fakultas Ekonomi Universitas Negeri Malang: Jurusan Akuntansi, Manajemen Dan Ekonomi Pembangunan" Jurnal Nominal, Volume II. Nomor II. Diakses 15 Oktober 2015.

Lestari, Retno Budi dan Wijaya, Trisnadi. 2012. "Kewirausahaan Terhadap Minat Berwirausaha Mahasiswa di STIE MDP, STMIK MDP, dan STIE MUSI". Jurnal Ilmiah STIE MDP, Vol. 1. No. 2: 119.

Longenecker. Moore. Petty. 2001. Kewirausahaan Managemen Usaha Kecil. Jakarta: Salemba Empat.

Mahanani, Hanum Risfi. 2014. "Analisis Pengaruh Faktor Internal Dan Faktor Lingkungan Eksternal Terhadap Minat Berwirausaha”. Skripsi. Universitas Diponegoro.

Maharani, Dian Mega. 2013. "Perilaku Kewirausahaan Pedagang Etnis Cina Dan Pedagang Etnis Jawa Di Pasar Yaik Permai Semarang”. Skripsi. 
Universitas Negeri Semarang.

Marini,Chomzana Kinta. 2014. "Pengaruh Self-efficacy, Lingkungan keluarga, danLingkungan Sekolah Terhadap Minat Berwirausaha Siswa SMK Jasa Boga". Jurnal Pendidikan Vokasi, Vol 4. Nomor 2. Diakses pada tanggal 11 September 2015

Martono, Nanang. 2011. Metode Penelitian Kuantitatif. Jakarta: Rajawali Press.

Nopalia. 2012. "Pengaruh Penggunaan Informasi Akuntansi Manajemen Dan Kepribadian Wirausaha Terhadap Kinerja Manajerial". e-Jurnal BINAR AKUNTANSI, Vol.1. No. 1: 42-50. Diakses 29 Oktober 2014.

Patel, K. (2007). Understanding the Influence of Famili context on Entrepreneurial Characteristics. Gordon Institute of Business Science: Universitas of Preto-ria.

Paulina, Irene. 2011. "Pengaruh Kecerdasan Emosi, Sikap Mandiri, Dan Lingkungan Terhadap Intensi Berwirausaha Pada Mahasiswa Universitas Gunadarma”. Skripsi. Universitas Gunadarma.

Riyanti, Benedicta Prihatin Dwi. 2003. Kewirausahaan dari Sudut Pandang Psikologi Kepribadian. Jakarta: PT.Grasindo.

Sjarkawi. 2008. Pembentukkan Kepribadian Anak. Jakarta: Bumi Aksara.

Sugiyono. 2009. Metode Penelitian Kuantitatif, Kualitatif dan R\&D. Bandung: Alfabeta.

Sujanto, Agus. 2006. Psikologi Kepribadian. Jakarta: Bumi Aksara.

Suryana. 2001. Kewirausahaan. Jakarta: PT Salemba Empat.

Suryana. 2003. Kewirausahaan Pedoman Praktis, Kiat dan Proses Menuju Sukses. Bandung: Salemba Empat.

Suryana. 2009. Kewirausahaan, Pedoman Praktis: Kiat dan Proses Menuju Sukses. Jakarta: Salemba Empat.

Undang-Undang Republik Indonesia Nomor 20 Tahun 2003 tentang Sistem Pendidikan Nasional. 2010. Bandung: Diperbanyak oleh CV. Fokusmedia.

Walgito. B. 2002. PsikologiSosial (Suatu Pengantar). Yogyakarta: ANDI.

Yusuf, Syamsu. 2008. Teori Kepribadian. Bandung: PT.Remaja Rosdakarya.

Yusuf, Syamsu. 2009. Psikologi Perkembangan Anak \& Remaja. Bandung: Remaja Rosdakarya.

Zimmerer. T.W. Scarborough. N.M. 2008. Kewirausahaan dan Manajemen Usaha Kecil. Jakarta: Salemba Empat.

Zuchdi, Darmiyati. 2008. Humanisasi Pendidikan. Jakarta: Bumi Aksara 